\title{
THE SCIENTIFIC SUMMARY OF MONITORING RESULTS OF EXPENDITURE FOR SOCIAL PROTECTION IN THE EUROPEAN UNION AND UKRAINE
}

\author{
M.V.Zarichkova \\ National University of Pharmacy \\ Key words: social protection; functions of social protection; social risks
}

\begin{abstract}
This article deals with the study of expenditure for social protection in the European Union (EU) and Ukraine, which is the criterion characterising the level of public liability for support of a certain standard of living of the poorest social groups. During the study it has been found that social expenditure is meant to be the provision of households and individuals with assistance and other financial resources by public or private institutions for the purposes of their support ensuring and reducing of the risks in certain circumstances, which make their lives worse. The structure of expenditure for social protection has been analysed and grouped by the functions in Ukraine for 2012-2014. It has been determined that the bulk of social benefits is oriented to the people of the retirement age and the healthcare. The analysis of the structure of expenditure for social protection in the EU has shown that the funds allocated to the retirement assistance constitute a significant part of expenditure for social protection in the EU.
\end{abstract}

Today the problem of social and economic development of countries becomes pressing. Ukraine is no exception, it is characterised by considerable number of unsolved social and economic problems. Thus, the total expenditure for the social sector in Ukraine is quite considerable compared to EU countries, but the bulk of social benefits is oriented to the people of the retirement age and the healthcare. However, the quality of social services and other measures of social protection in Ukraine is still rather low, and social needs of the most vulnerable groups are not met in the appropriate way. Social protection should cover all types of interference by public or private organizations, which are aimed to facilitate households and individuals for the social risks or needs. Therefore, using the methodology of the European system of the integrated social protection statistics (ESSPROS) the risks or needs, which can lead to social protection in Ukraine, have been identified. The abovementioned information determines the relevance of the topic of the article chosen.

The aim of the article is to study the structure of expenditure for social protection in the European Union and Ukraine, as well as to determine its content and functions. The study subject is the structure of expenditure for social protection in the European Union and Ukraine, and for risks or needs, which lead to social protection in Ukraine according to the ESSPROS.

\section{Materials and Methods}

During the study the methods of logical, historical, analytical analysis and sociological research were used. The expenditure for social protection in the EU and Ukraine was analysed as a percentage to GDP, and the existing social risks or needs according to the ESSPROS methodology, which could lead to social protection, were grouped.

\section{Results and Discussion}

The uniform methodological approaches to the analysis of expenditure for social protection in the EU and Ukraine were used making impossible their comparison (Tab. 1). At the same time, social costs are presented as a proportion of the gross domestic product; they are the recognized criterion characterising the level of public liability for support of a certain standard of living of the most vulnerable social groups. The social expenditures are considered to be the provision of households and individuals with assistance and other financial resources by public or private institutions for the purposes of their support ensuring and reducing of the risks in certain circumstances, which make their lives worse $[1,3,6]$.

The comparative analysis of expenditure for social protection in Ukraine and the European Union showed that countries with the highest ratio of expenditures for social protection to GDP such as France (33.7\%), Denmark (33.3\%), the Netherlands (31.3\%) and Finland (31.2\%) spent twice more for social purposes than three countries with the lowest ratio - Latvia (14.4\%), Estonia and Romania (14.8\% each). In Ukraine, the figure in 2013 was $23.7 \%$ (in 2014 it was $22.2 \%$ ) (Fig. 1) [1, 3-5].

As can be seen from Fig. 1, Ukraine is included to the top ten countries with the high level of social protection, which was $23.7 \%$ to GDP in 2013. However, it does not mean that the social protection in our country is at high level. According to our research concerning this issue there is a great difference between the level of expenditure for social protection in the EU and Ukraine. For example, there are differences between the EU Member States in absolute terms of social expenditures per capital at purchasing power parity (PPP). In 2013 their value fluctuated from 2201 Euros in Romania to 14466 Euros in Luxembourg. If social expenditure in Luxembourg 
Table 1

Analysis of the expenditure for social protection in the EU countries and Ukraine as a percentage to GDP

\begin{tabular}{|l|c|c|c|c|}
\hline \multirow{2}{*}{\multicolumn{1}{|c|}{ Countries }} & \multicolumn{4}{c|}{ Years } \\
\cline { 2 - 5 } & 2010 & 2011 & 2012 & 2013 \\
\hline Austria & 29.6 & 28.9 & 29.2 & 29.8 \\
\hline Belgium & 29.4 & 29.7 & 29.9 & 30.2 \\
\hline Bulgaria & 17.3 & 16.7 & 16.7 & 17.6 \\
\hline UK & 28.8 & 28.7 & 28.8 & 28.1 \\
\hline Denmark & 32.8 & 32.3 & 32.2 & 33.3 \\
\hline Estonia & 17.6 & 15.6 & 15.0 & 14.8 \\
\hline Ireland & 24.5 & 23.2 & 23.0 & 22.0 \\
\hline Spain & 24.7 & 25.4 & 25.5 & 25.7 \\
\hline Italy & 28.8 & 28.5 & 29.3 & 29.8 \\
\hline Cyprus & 20.1 & 20.8 & 21.0 & 22.3 \\
\hline Latvia & 18.1 & 15.1 & 14.2 & 14.4 \\
\hline Lithuania & 18.9 & 16.9 & 16.3 & 15.3 \\
\hline Luxembourg & 22.9 & 22.3 & 23.0 & 23.1 \\
\hline Malta & 18.7 & 18.2 & 18.5 & 18.7 \\
\hline Netherlands & 29.9 & 30.1 & 30.9 & 31.3 \\
\hline Germany & 29.8 & 28.6 & 28.7 & 29.0 \\
\hline Poland & 19.6 & 18.6 & 17.7 & 16.7 \\
\hline Portugal & 25.8 & 25.8 & 26.4 & 27.6 \\
\hline Romania & 17.3 & 16.4 & 15.4 & 14.8 \\
\hline Slovakia & 24.3 & 17.9 & 18.1 & 18.4 \\
\hline Slovenia & 22.7 & 24.5 & 24.9 & 25.0 \\
\hline Hungary & $\mathbf{2 5 . 3}$ & $\mathbf{2 3 . 2}$ & $\mathbf{2 4 . 0}$ & $\mathbf{2 3 . 7}$ \\
\hline Ukraine & 29.2 & 28.8 & 30.1 & 31.2 \\
\hline Finland & 20.7 & 32.5 & 33.3 & 33.7 \\
\hline France & 20.4 & 20.9 & 21.7 \\
\hline Croatia & 20.1 & 20.5 & 20.2 \\
\hline Czech Republic & 29.3 & 30.0 \\
\hline Sweden & 28.7 & & \\
\hline
\end{tabular}

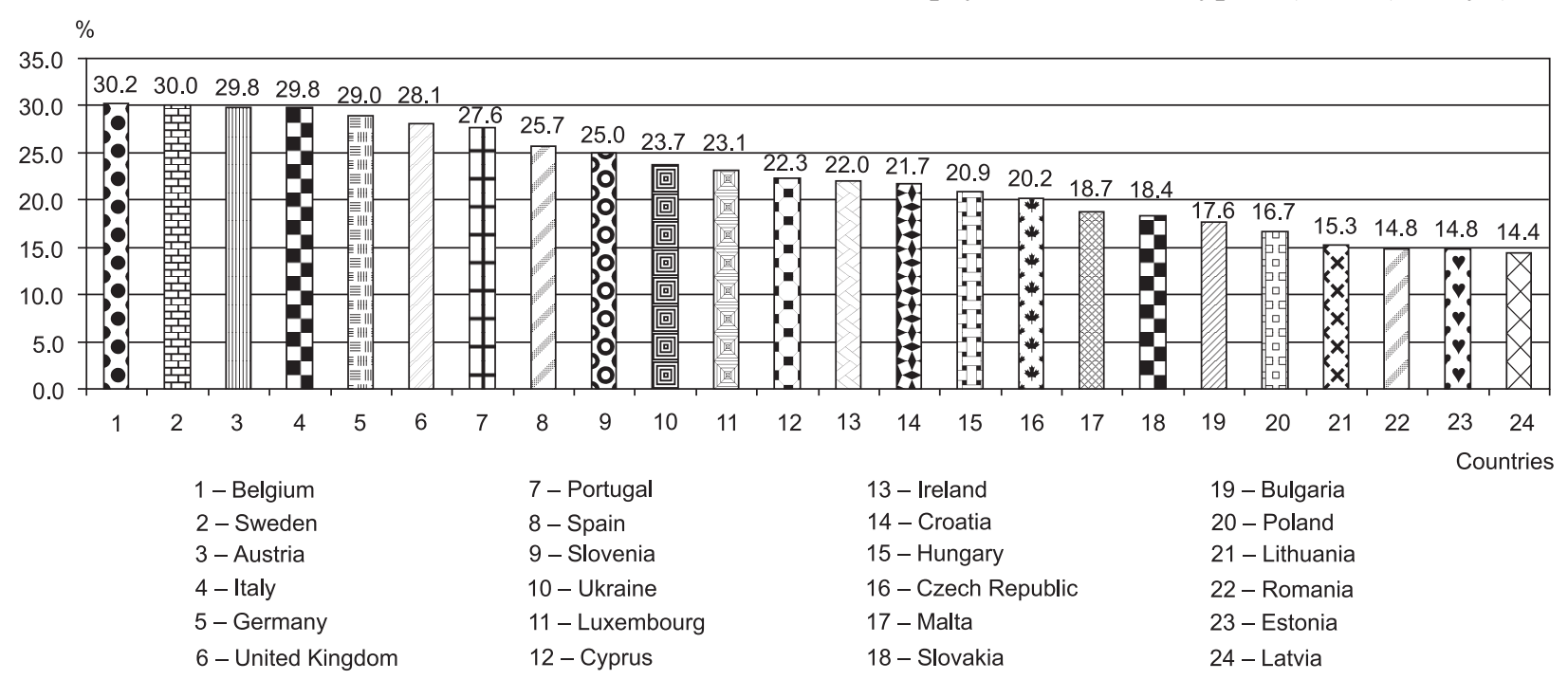

was 1206 Euros per capita a month, they were 183 and 193 Euros in Romania and Bulgaria, respectively. As for Ukraine, in 2013 the expenditure for social protection per capita was 1542 Euros at PPP, or 129 Euros per a month [10].

It has been determined that the differences between the European countries in terms of expenditure for social protection may be partially related to different levels of welfare and prices, reflecting, in addition, differences in the systems of social protection, demographic trends, unemployment rates and other social, institutional and economic factors.

In particular, the structure of social expenditure itself is different in the EU. Thus, the share of expenditure for social assistance and benefits in 2013 fluctuated from $93.6 \%$ of social expenditure in the Netherlands to 98.9\% in the United Kingdom, Malta and Estonia. Administrative costs ranged from $1.1 \%$ of the total expenditure in such countries as Cyprus, Malta, Estonia and the United Kingdom to $5.3 \%$ in Ireland. In addition, in some countries rather significant part of the funds for social security was charged to other expenses: in Portugal $-4.2 \%$ and Lithuania $-3.1 \%$. In Ukraine, in 2013 the structure of social expenditure was as follows: $98.1 \%-$ social assistance (in 2014 - 98.3\%), 1.4\% - administrative expenses $(1.2 \%)$ and $0.5 \%$ - other expenditure $(0.5 \%)$.

The studies have shown that most social assistance is provided regardless of wealth, i.e. without checking the recipients for poverty. In general, within the EU only a tenth of the funds oriented to social protection was stipulated by the level of welfare of its recipients. The value of social assistance was rather higher in Ireland $(31.9 \%)$ and the United Kingdom (14.3\%) in 2013. In Ukraine, only $3.1 \%$ of the funds $(3.7 \%$ in 2014$)$ oriented to social assistance were stipulated by the level of welfare of its recipients in 2013. This includes targeted social assistance, i.e. housing subsidies and low-income family assistance.

Totally, more than $60 \%$ of all expenditures for social protection were in cash in the EU in 2013. The biggest share of payments was in Cyprus (82.2\%), Italy (75.4\%)

Fig. 1. The comparative analysis of expenditure for social protection in the EU countries and Ukraine in 2013. 


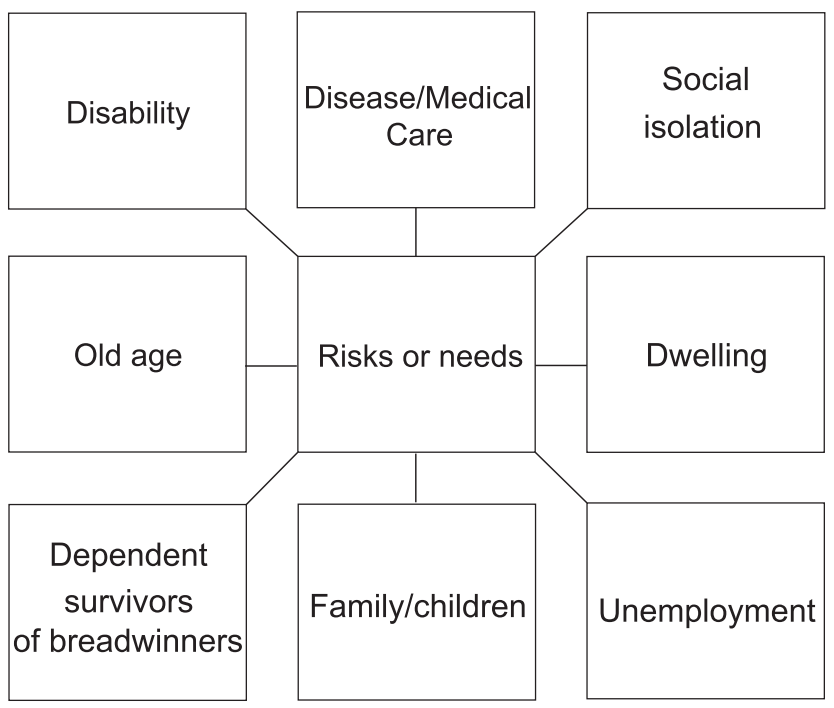

Fig. 2. Identified risks or needs, which can lead to social protection in Ukraine according to the ESSPROS

and Latvia (74.0\%). In Ukraine, $82.0 \%$ of the total social assistance was given in cash in 2013 (in 2014 - 82.9\%).

We have found out that the total expenditure for the social sector in Ukraine is quite large in comparison with the EU countries, but the quality of social services and other measures of social protection in Ukraine is still rather low, and social needs of the most vulnerable groups are not met in the appropriate way.

Social protection should cover all types of interference by public or private organizations, which are aimed to facilitate households and individuals for the social risks or needs. That is why using the methodology of the European system of the integrated social protection statistics (ESSPROS) risks or needs, which can lead to social protection in Ukraine, have been identified (Fig. 2) [2-5].

According to Fig. 2 this list of risks or needs, on the one hand, limits the amount of social security by areas, which are the most relevant in the European context; on the other hand, it serves as a tool for comparable statistics when institutions, regulations and social traditions of the countries differ radically. Various risks and needs determine the priority of the objects, which the funds and assistance are intended for regardless of legislative or institutional structures. The term "the function of social protection" is usually used in this context.
Based on the previous research and the data of the State Statistics Service the structure of expenditure for social protection by the functions in Ukraine for 2012-2014 are presented (Tab. 2) [1, 7-9].

According to Tab. 2 the bulk of social benefits is oriented to the people of the retirement age and the healthcare. In Ukraine, this item of expenditure for social protection is the most important and the greatest among all European countries. In 2013 expenses for the function "Old Age" were $64.0 \%$ of all expenses for social protection (14.9\% of GDP) and in $2014-65.5 \%$ (14.3\% of GDP).

Comparing the situation in the EU it can be noted that the funds allocated to the retirement assistance constitute the significant part of the costs for social protection. For example, in 2013 the value of these expenditures was particularly high in Latvia, Italy and Romania where they were $53.2 \%, 50.7 \%$ and $50.1 \%$ of the total expenditure for social protection, respectively. The factors, which contribute to such level of this type of social assistance, include rather high proportion of the population over 65 and older (at the beginning of 2014 it was $21.4 \%$ of the population in Italy to $18.5 \%$ on average in EU-28). On the contrary, in Ireland this assistance was only $27.5 \%$ of the total social expenses. This is partially related to the fact that the population in Ireland is the youngest in Europe: at the beginning of $201428.0 \%$ of the population in Ireland were younger than 20 years (the average value in the EU-28 was $21.0 \%$ ), and only $12.6 \%$ of the population in this country were older than 65 years.

Assistance for disease and medical care was analysed next. It was found that in 2013 it was the second in the EU in the ratio of the total expenditure for social protection. In the Netherlands and Croatia their value was the highest among expenditure for social protection and constituted $35.4 \%$ and $34.9 \%$ of all social expenditure, respectively. Instead, in Denmark and Cyprus it was only $20.2 \%$ and $20.6 \%$ of the total expenditure for social protection.

In Ukraine, this item is also the second among all types of expenditures, but it has even lower rates than Denmark and Cyprus. In 2013, the share of this expenditure was $18.1 \%$ of the total expenditure for social

Table 2

Expenditure for social protection by the functions in Ukraine

\begin{tabular}{|l|c|c|c|c|c|c|}
\hline \multirow{2}{*}{ Social protection assistance } & \multicolumn{2}{c|}{2012} & \multicolumn{2}{c|}{2013} & \multicolumn{3}{c|}{2014} \\
\cline { 2 - 7 } & thousand UAH & $\%$ & thousand UAH & $\%$ & thousand UAH & $\%$ \\
\hline Disease/Medical Care & 60509773.7 & 17.6 & 64076027.4 & 18.1 & 55742945.8 & 16.1 \\
\hline Disability & 4527877.0 & 1.3 & 4015557.2 & 1.1 & 4170317.1 & 1.2 \\
\hline Old age & 226011000.3 & 65.7 & 226791082.8 & 64.0 & 226572634.0 & 65.5 \\
\hline Dependent survivors of breadwinners & 2514348.3 & 0.7 & 2550428.7 & 0.7 & 2511185.8 & 0.7 \\
\hline Family/children & 35340490.7 & 10.3 & 39691901.9 & 11.2 & 38932434.0 & 11.2 \\
\hline Unemployment & 5438379.0 & 1.6 & 6382967.6 & 1.8 & 5385406.9 & 1.6 \\
\hline Dwelling & 7455762.9 & 2.2 & 6779027.7 & 1.9 & 6887514.9 & 2.0 \\
\hline Social isolation & 2095599.9 & 0.6 & 4050674.4 & 1.2 & 5942094.9 & 1.7 \\
\hline Total & $\mathbf{3 4 3 8 9 3 \mathbf { 2 3 1 . 8 }}$ & $\mathbf{1 0 0 . 0}$ & $\mathbf{3 5 4 3 3 7 6 6 7 . 7}$ & $\mathbf{1 0 0 . 0}$ & $\mathbf{3 4 6} \mathbf{1 4 4 5 3 3 . 4}$ & $\mathbf{1 0 0 . 0}$ \\
\hline
\end{tabular}


protection (4.2\% of GDP), and in $2014-16.1 \%(3.5 \%$ of GDP).

Disability assistance in the EU differs significantly in various countries in the structure of the total expenditure for social protection. In 2013 in Croatia and Denmark it was $17.0 \%$ and $13.1 \%$, respectively, while in Cyprus and Malta less than $4 \%$ of social expenditure were consumed for this purpose $(3.3 \%$ and $3.9 \%$, respectively).

In Ukraine, this item of expenditure is one of the smallest. In $20131.1 \%$ of all expenditure for social protection, or $0.3 \%$ of GDP was consumed in total for this item of expenditure; in $2014-1.2 \%$ or $0.3 \%$ of GDP.

To support families and children in 2013 the most funds were allocated in Luxembourg (15.9\% of the total social expenditure), Ireland (13.4\%) and Hungary (12.1\%). At the same time, the Netherlands, Italy and Portugal spent less than $5 \%$ of social expenses for this purpose.

In Ukraine in 2013 this expenditure item was the third in terms of all expenditure items $(11.2 \%$ of the total expenditures or $2.6 \%$ of GDP). In 2014 expenditure was also $11.2 \%$ of all expenses $(2.5 \%$ of GDP).

The studies demonstrated that the major differences between the EU Member States were in the ratio of social expenditure oriented to solving the problem of unemployment. Expenditure for social protection of the unemployed in 2013 fluctuated from $14.7 \%$ of the total expenditure for social protection in Ireland to $1.1 \%$ in Romania.

In Ukraine expenses on unemployment problems were also low, and in 2013 constituted $1.8 \%$ of the total expenditure for social protection, or $0.4 \%$ of GDP. In 2014 there was a slight decrease up to $1.6 \%$, which was $0.3 \%$ of GDP.

Assistance to dependent survivors of breadwinners was funded most in 2013 in Croatia (9.8\% of the total expenditure for social protection), Spain (9.7\%) and Italy $(9.3 \%)$. The least expenditure for dependents was in the United Kingdom and Estonia where it did not exceed $0.5 \%$ of the total expenditure.

Ukraine in 2013 and 2014 spent $0.7 \%$ of the total expenditure for social protection on this item each year; it was $0.2 \%$ of GDP in both years.

Relatively small funds in the EU are directed to solve housing problems. In 2013 the largest expenditure for housing was recorded in the United Kingdom (5.2\%), while at the same time in Portugal, Lithuania, Bulgaria, Slovenia and Croatia less than $0.1 \%$ of the total social expenditure was allocated for this purpose. Small social expenditure for housing is typical both for Ukraine and for the European Union. In 2013 and 2014 it was 1.9\% and $2.0 \%$ of the total expenditure for social protection, respectively ( $0.4 \%$ of GDP).

Expenses on social isolation in the EU in 2013 were the smallest expenditure item. Only the Netherlands and
Cyprus spent for this type of social protection 5.2\% and $5.0 \%$, respectively. Most countries spent $2 \%$ on average of the total expenditure, and Croatia, Hungary, Germany, Italy, Estonia, Spain, Portugal, Ireland and Latvia spent less than $1 \%$ of the total expenditure for this type of social protection.

In Ukraine, the expenditure for social isolation is also one of the least funded item of expenditures for social protection. However, it should be noted that the expenditure for this item has increased: in 2012 it was only $0.6 \%$, while in 2013 the expenditure for social isolation increased to $1.2 \%$, and in 2014 it increased to $1.7 \%$ of the total expenditure for social protection $[2,3,8,9,10]$.

CONCLUSIONS

Based on the study conducted the conclusion can be made that the total expenditure for social protection and social security in Ukraine is quite large, even compared to the developed European countries. However, despite the considerable amount of social expenses, the quality of social services and other measures of social protection in Ukraine is still rather low, and social needs of the most vulnerable groups are not met in appropriate way.

It has been found that the differences between European countries and Ukraine in terms of expenditure for social protection may be partially related to different levels of welfare, prices and differences in the systems of social protection, demographic trends, unemploymentrates and other social, institutional and economic factors. The studies have shown that most social assistance is provided regardless of wealth, i.e. without checking the recipients for poverty. In general, within the EU only a tenth of the funds oriented to social protection was stipulated by the level of welfare of its recipients. In Ukraine in 2013 only $3.1 \%$ of the funds (3.7\% in 2014) oriented to social assistance were stipulated by the level of welfare of its recipients. This includes targeted social assistance, i.e. housing subsidies and low-income family assistance.

The analysis has shown that systematic implementation of the European legislation needs to change the relevant instruments of social protection and reconsider the basic functions of social protection in Ukraine taking into account quantitative and qualitative statistical indicators of social protection according to the European system of the integrated social protection statistics (ESSPROS).

It has been determined that the bulk of social benefits is oriented to the people of the retirement age and the healthcare. In Ukraine, this item of expenditure for social protection is the most important and the greatest among all European countries. In 2013 expenses for the function "Old Age" constituted $64.0 \%$ of all expenses for social protection (14.9\% of GDP) and in $2014-65.5 \%$ (14.3\% of GDP).

\section{REFERENCES}

1. Конституція України // Офіиіийний вісник України. - 2010. - №72/1. - 2598 с.

2. Соиіальний захист. Дані Державної служби статистики Украӥни. [Електронний ресурс]. - Режим docmyny: http://ukrstat.gov.ua 
3. Національні рахунки соціального захисту України // Статистичний бюллетень. - 2014. - 133 с.

4. Толочко В.М., Зарічкова М.В. // Вісник фармачії. - 2012. - №2. - С. 37-39.

5. European social Policy Forum. Brussels, 24-26 June. 1998. Summary report/Ed. by M.Carley. -№29, $28,88$.

6. Imai K. // J. of Computational and Graphical Statistics. - 2008. - Vol. 17, №4. - P. 1-22. [Електронний pесурс]. - Режсим достуny: http://gking.harvard.edu/files/z.pdf

7. Imai K., King G., Lau O. // J. of Computational and Graphical Statistics. - 2008. - Vol. 17, №4. - P. 1-22. DOI: 10.1198/106186008X384898. - [Електронний ресурс]. - Режим достуny: http://gking.harvard.edu/ files/z.pdf

8. Tolochko V., Zarichkova M., Medvedyeva Y., Tolochko K. //Intern. J. of Fharmac. Sci. Rev. and Res. - 2013. - JanuaryFebruary, Vol. 18, Issue 1. - [Електронний pecypc]. - Режим достуny: http://www.globalresearchonline. net/pharmajournal/vol18iss1.aspx

9. Wickham H. // J. of Statistical Software. - 2011. - Vol. 40, №1. - P. 1-29. [Електронний ресурс]. - Режим docmyny: http://www.jstatsoft.org/v40/i01/paper

10. Zarichkova M.V. // The Pharma Innovation J. - 2016. - Vol. 5, №8. - P. 77-82.

НАУКОВЕ УЗАГАЛЬНЕННЯ РЕЗУЛЬТАТІВ МОНІТОРИНГУ ВИДАТКІВ НА СОЦІАЛЬНИЙ ЗАХИСТ У КРАЇНАХ ЄВРОПЕЙСЬКОГО СОЮЗУ ТА В УКРАЇНІ

\section{М.В.Зарічкова}

Ключові слова: соціальний захист; фуннції соціального захисту; соціальні ризики

Досліджені витрати на соціальний захист у країнах Європейського Союзу (ЄC) та України, що є критерієм, який характеризує ступінь державної відповідальності з підтримки певного стандарту життя найбідніших верств населення. В ході проведення досліджень було визначено, що під соціальними видатками розуміють надання громадськими чи приватними інституціями допомога та інших фрінансових коштів домогосподарствам та окремим особам з метою забезпечення їх підтримки та зниження ризиків у певних обставинах, що погіршують їх життя. Проаналізовано та угруповано структуру видатків на соціальний захист за фуннкціями в Україні за 2012-2014 роки. Встановлено, що основний обсяг соціальних виплат спрямовується на осіб пенсійного віку та медичне обслуговування. Проведений аналіз структури видатків на соціальний захист в ЄС показав, що кошти, направлені на допомогу у зв'язку з виходом на пенсію, складають значну частину витрат на соціальний захист у ЄС.

\section{НАУЧНОЕ ОБОБЩЕНИЕ РЕЗУЛЬТАТОВ МОНИТОРИНГА РАСХОДОВ НА СОЦИАЛЬНУЮ ЗАЩИТУ В СТРАНАХ ЕВРОПЕЙСКОГО СОЮЗА И В УКРАИНЕ М.В.Заричкова}

Ключевые слова: социальная защита; фрункции социальной защиты; социальные риски Исследованы расходы на социальную защиту в странах Европейского Союза (EC) и в Украине, которые являются критерием, характеризующим степень государственной ответственности по поддержанию определенного стандарта жизни беднейших слоев населения. В ходе проведения исследований было определено, что под социальными расходами понимают предоставление общественными или частными учреждениями пособий и других фринансовых средств домохозяйствам и отдельным лицам с целью обеспечения их поддержки и снижения рисков в определенных обстоятельствах, ухудшающих их жизнь. Проанализирована и сгруппирована структура расходов на социальную защиту по фрункциям в Украине за 2012-2014 годы. Установлено, что основной объем социальных выплат направлен на лиц пенсионного возраста и медицинское обслуживание. Проведенный анализ структуры расходов на социальную защиту в EC показал, что средства, направленные на помощь в связи с выходом на пенсию, составляют значительную часть расходов на социальную защиту в $E C$. 